\title{
Serosurveillance and Molecular Investigation of Wild Deer in Australia Reveals Seroprevalence of Pestivirus Infection
}

\author{
Jose L. Huaman ${ }^{1,2}$, Carlo Pacioni ${ }^{3,4}$, David M. Forsyth ${ }^{5}$, Anthony Pople ${ }^{6}$, \\ Jordan O. Hampton ${ }^{4,7}$, Teresa G. Carvalho ${ }^{2}$ ad and Karla J. Helbig 1,*(D) \\ 1 Department of Physiology, Molecular Virology Laboratory, Anatomy and Microbiology, School of Life \\ Sciences, La Trobe University, Melbourne 3086, Australia; j.huamantorres@latrobe.edu.au \\ 2 Department of Physiology, Molecular Parasitology Laboratory, Anatomy and Microbiology, School of Life \\ Sciences, La Trobe University, Melbourne 3086, Australia; t.carvalho@latrobe.edu.au \\ 3 Department of Environment, Land, Water and Planning, Arthur Rylah Institute for Environmental Research, \\ Heidelberg 3084, Australia; carlo.pacioni@delwp.vic.gov.au \\ 4 School of Veterinary and Life Sciences, Murdoch University, South Street, Murdoch, WA 6150, Australia; \\ jordan.hampton@murdoch.edu.au \\ 5 NSW Department of Primary Industries, Vertebrate Pest Research Unit, Orange 2800, Australia; \\ dave.forsyth@dpi.nsw.gov.au \\ 6 Department of Agriculture and Fisheries, Invasive Plants \& Animals Research, Biosecurity Queensland, \\ Ecosciences Precinct, Brisbane 4102, Australia; tony.pople@daf.qld.gov.au \\ 7 Ecotone Wildlife, P.O. Box 76, Inverloch, VIC 3996, Australia \\ * Correspondence: k.helbig@latrobe.edu.au; Tel.: +61-3-9479-6650
}

Received: 28 May 2020; Accepted: 8 July 2020; Published: 13 July 2020

\begin{abstract}
Since deer were introduced into Australia in the mid-1800s, their wild populations have increased in size and distribution, posing a potential risk to the livestock industry, through their role in pathogen transmission cycles. In comparison to livestock, there are limited data on viral infections in all wildlife, including deer. The aim of this study was to assess blood samples from wild Australian deer for serological evidence of exposure to relevant viral livestock diseases. Blood samples collected across eastern Australia were tested by ELISA to detect antigens and antibodies against Pestivirus and antibodies against bovine herpesvirus 1. A subset of samples was also assessed by RT-PCR for Pestivirus, Simbu serogroup, epizootic hemorrhagic disease virus and bovine ephemeral fever virus. Our findings demonstrated a very low seroprevalence (3\%) for ruminant Pestivirus, and none of the other viruses tested were detected. These results suggest that wild deer may currently be an incidental spill-over host (rather than a reservoir host) for Pestivirus. However, deer could be a future source of viral infections for domestic animals in Australia. Further investigations are needed to monitor pathogen activity and quantify possible future infectious disease impacts of wild deer on the Australian livestock industry.
\end{abstract}

Keywords: Australia; deer; prevalence; Pestivirus; ruminants; serosurveillance; virology; wildlife disease

\section{Introduction}

Deer (family Cervidae) often attain high densities when introduced to new areas [1]. As cervids are ungulates and closely related to economically important livestock species including cattle, sheep and goats, it is unsurprising that they share many pathogens, including several of major agricultural relevance. Many viral pathogens of farm ruminants have been detected in wild cervids globally, the 
most important of which are bovine viral diarrhea virus (BVDV), bovine herpesvirus 1 (BoHV-1), epizootic hemorrhagic disease virus (EHDV) and bovine ephemeral fever virus (BEFV) [2-6].

In Australia, wild populations of six non-native deer species became established in the late 1800s and early 1900s. These populations have expanded in abundance and distribution [1,2]. Wild deer in Australia commonly share grazing areas with livestock, and their susceptibility to a wide range of viral infections of importance to the livestock industry has been demonstrated [2]. Hence, wild deer represent a significant potential source of pathogen transmission to livestock [1].

Australian agriculture is currently free from many viral diseases that impact livestock industries in other parts of the world, including foot-and-mouth disease (FMD) and louping ill virus. However, the issue of cervid-transmitted disease in Australia is important because incursions or outbreaks of emerging, exotic or endemic disease could cause serious production losses, resulting in substantial economic impacts for the livestock industry [1,2]. Transmission of disease by cervids could also prevent effective control, management or eradication of a livestock disease, resulting in prolonged epidemics [2].

There is currently limited information about the infection status of Australia's wild deer populations. A small number of studies assessed the distribution of BVDV in wild fallow (Dama dama) and red (Cervus elaphus) deer populations in the 1970s and 1980s [7,8], but these were conducted in small geographical areas. Moreover, serological studies of endemic livestock viruses including BEFV, EHDV and Simbu serogroup virus were performed in red deer from Queensland [9] and rusa deer (Rusa timorensis) from New South Wales [10]. Therefore, the role wild deer might play in the spread of diseases to livestock remains unclear. Addressing this knowledge gap is important for anticipating how viruses might be transmitted to other animals, and how diseases might be controlled. The objective of this study was to assess whether Australian wild deer populations are exposed to relevant viral livestock diseases by testing blood samples for antibodies and antigens or through detection of viral genetic material. Our results establish a baseline exposure level, and possible spreading patterns in Australia's wild deer.

\section{Materials and Methods}

\subsection{Sampling}

Blood samples were collected by recreational hunters and professional culling staff from deer populations across eastern Australia. Most of the sampling areas were located within a 1- to 10-kilometer radius from agricultural grazing areas (Table 1, Figure 1A). Samples were generally collected during field necropsies in cooler winter months (Table 1, Figure 1B), when most culling and hunting occurs in Australia. Blood was drawn from the jugular vein and/or the heart and thoracic cavity, and collected in tubes (Becton Dickinson, Franklin Lakes, NJ, USA) with and without anticoagulant (EDTA) to obtain plasma and serum, respectively. Collection tubes were immediately refrigerated and transported to the laboratory. At the laboratory, serum and plasma were separated by centrifugation (10 min at $2000 \mathrm{~g}$ ), transferred to $1.5 \mathrm{~mL}$ screw capped vials and stored at $-80^{\circ} \mathrm{C}$ until assayed. 
Table 1. Population characteristics and distribution of deer sampled and tested in this study.

\begin{tabular}{|c|c|c|c|c|c|c|c|c|c|c|c|c|c|c|c|c|c|c|c|c|c|c|}
\hline \multirow{2}{*}{$\begin{array}{l}\text { States or } \\
\text { Territory }\end{array}$} & \multirow[b]{2}{*}{ Animals } & \multirow[b]{2}{*}{ Sampling Location } & \multirow[b]{2}{*}{ Species } & \multicolumn{3}{|c|}{ Sex } & \multicolumn{4}{|c|}{ Age Groups } & \multicolumn{9}{|c|}{ Month of Sampling } & \multicolumn{3}{|c|}{ No. Deer Tested by } \\
\hline & & & & $\mathbf{M}$ & F & N.r. & Ad & Yrl & Fw & N.r. & Feb & Mar & Apr & May & Jun & Jul & Aug & Oct & Nov & $\begin{array}{l}\text { ELISA } \\
\mathbf{A b}\end{array}$ & $\begin{array}{c}\text { ELISA } \\
\text { Ag }\end{array}$ & PCR \\
\hline \multirow{3}{*}{ NSW } & \multirow{3}{*}{244} & Liverpool Plains * & \multirow{3}{*}{$\begin{array}{c}\text { Fallow } \\
\text { Rusa }\end{array}$} & 74 & 52 & 0 & 74 & 47 & 5 & 0 & 0 & 0 & 0 & 0 & 39 & 0 & 87 & 0 & 0 & 126 & 126 & 42 \\
\hline & & Eden * & & 12 & 21 & 5 & 21 & 9 & 3 & 5 & 0 & 0 & 0 & 0 & 0 & 0 & 18 & 15 & 5 & 38 & 0 & 18 \\
\hline & & Wollongong * & & 69 & 11 & 0 & 68 & 12 & 0 & 0 & 43 & 0 & 14 & 0 & 13 & 0 & 0 & 10 & 0 & 80 & 66 & 7 \\
\hline $\mathrm{ACT}$ & 34 & Canberra * & Fallow & 14 & 20 & 0 & 26 & 8 & 0 & 0 & 0 & 0 & 0 & 0 & 34 & 0 & 0 & 0 & 0 & 34 & 0 & 10 \\
\hline \multirow{4}{*}{ VIC } & \multirow{4}{*}{44} & Alpine National Park & \multirow{3}{*}{ Sambar } & 17 & 14 & 1 & 19 & 6 & 6 & 1 & 10 & 0 & 15 & 7 & 0 & 0 & 0 & 0 & 0 & 32 & 16 & 17 \\
\hline & & Upper Yarra Flats & & 2 & 6 & 1 & 6 & 1 & 1 & 1 & 0 & 0 & 0 & 0 & 8 & 0 & 0 & 1 & 0 & 9 & 8 & 4 \\
\hline & & \multirow{2}{*}{ Yellinbo } & & 0 & 1 & 0 & 0 & 0 & 1 & 0 & 0 & 0 & 0 & 0 & 0 & 1 & 0 & 0 & 0 & 1 & 0 & 1 \\
\hline & & & Fallow & 0 & 2 & 0 & 1 & 0 & 1 & 0 & 0 & 0 & 0 & 0 & 0 & 2 & 0 & 0 & 0 & 2 & 0 & 2 \\
\hline QLD & 110 & \multirow[t]{2}{*}{$\begin{array}{c}\text { North east } \\
\text { Queensland * }\end{array}$} & \multirow[t]{2}{*}{ Chital } & 41 & 69 & 0 & 90 & 20 & 0 & 0 & 0 & 47 & 0 & 0 & 5 & 0 & 0 & 0 & 58 & 110 & 105 & 43 \\
\hline Total & 432 & & & 229 & 196 & 7 & 305 & 103 & 17 & 7 & 53 & 47 & 29 & 7 & 99 & 3 & 105 & 26 & 63 & 432 & 321 & 144 \\
\hline
\end{tabular}

* Sampling was conducted in areas close to livestock farms; NSW: New South Wales; ACT: Australian Capital Territory; VIC: Victoria; QLD: Queensland; F: female, M: male, Ad: adult, Yrl: yearling, Fw: fawn, N.r.: Not recorded; chital deer (Axis axis), rusa deer (Rusa timorensis), sambar deer (Rusa unicolor), fallow deer (Dama dama). 

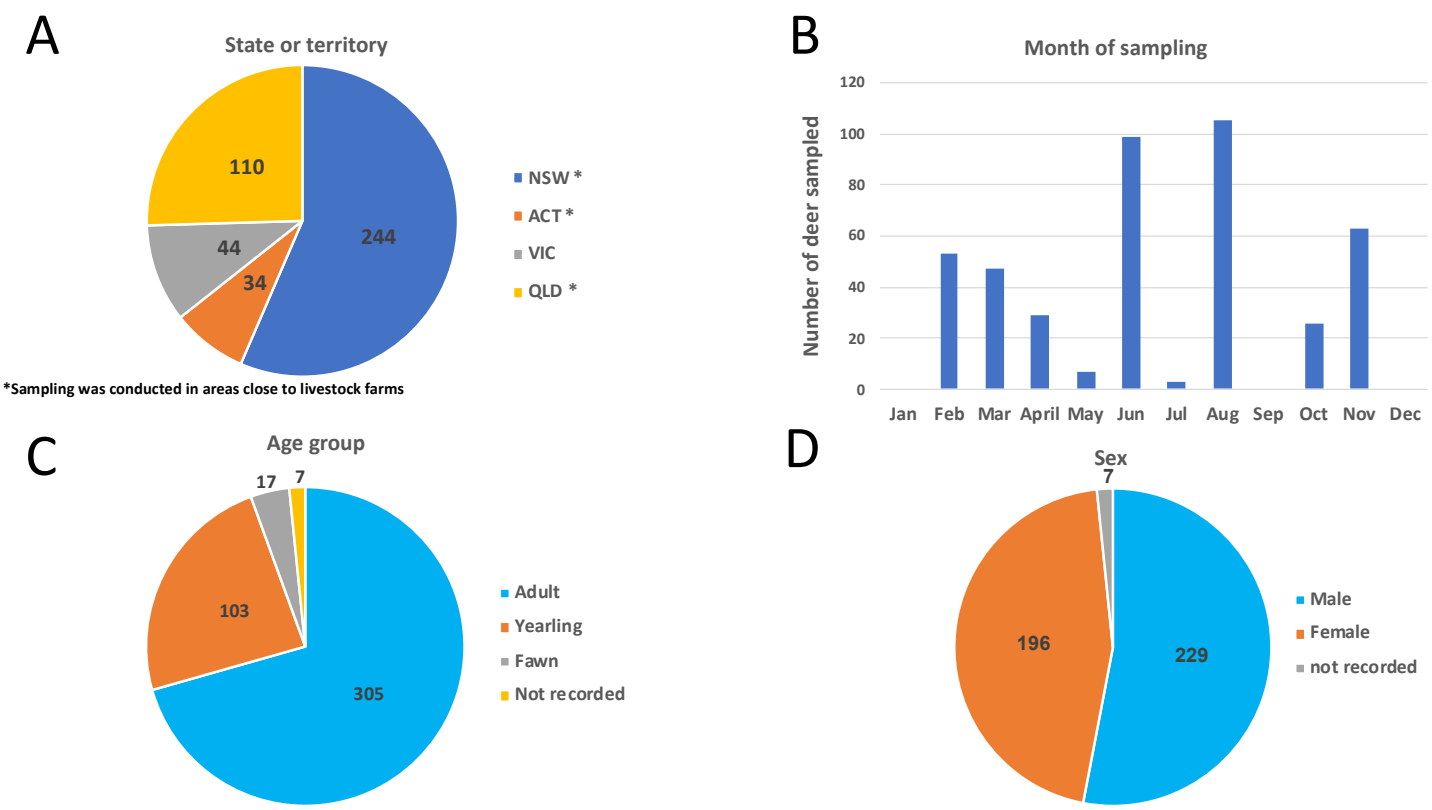

Figure 1. Population characteristics and distribution of deer sampled and tested in this study. Total numbers of deer sampled per region (A), per month (B), by age group (C) and by sex (D) are represented graphically.

\subsection{Serological Methods}

Serum and plasma were tested for Pestivirus antigen (Ag) and antibodies (Ab) against BoHV-1 and Pestivirus using the commercially available immunoenzymatic assay (ELISA) kits SERELISA ${ }^{\circledR}$ BVD p80 Ag Mono Indirect (Synbiotics SAS, Lyon, France), SERELISA BHV-1 Ab Mono Blocking ELISA (Synbiotics SAS, Lyon, France) and the PrioCHECK ${ }^{\mathrm{TM}}$ BVD \& BD p80 Serum Kit (ThermoFisher Scientific, Rockford, USA) according to the manufacturer's instructions. For BoHV-1, samples with a ratio OD (optical density) sample/OD negative control $\leq 0.5$ were classified as positive. This kit presents sensitivity (sn) of $96 \%$ and specificity (sp) 99\%, according with the manufacturer. The Pestivirus kit detects antibodies targeted against the protein (p80/125), common to all BVDV and border disease virus (BDV) strains, with a manufacturer reported $97 \%$ sn and $98 \%$ sp for BVDV and $96 \%$ sn and $100 \%$ sp for BDV. Inhibition percentage (\%INH) for each sample was calculated according to the manufacturer's kit insert.

Samples with a percentage inhibition (\%INH) of $<50$ were classified as negative, those with $50 \leq \% \mathrm{INH}<80$ as weak positive, and $\% \mathrm{INH} \geq 80$ as strong positive. Results for the Pestivirus antigen detection kit are expressed as an index $=0.5 \times$ OD sample-OD Positive control $(\mathrm{P})$. Any sample having an index $\geq(-0.15 \times \mathrm{ODP})$ was considered positive, $<(-0.3 \times \mathrm{ODP})$ was considered negative and between $(-0.15 \times \mathrm{OD} P)$ and $(-0.3 \times \mathrm{ODP})$ was considered doubtful according to the manufacturer's instructions.

Positive and negative controls were included in each run following the manufacturer's recommendations. Furthermore, all deer samples were initially tested in pools of three, with all serum samples in positive pools being additionally sampled individually and in duplicate. Optical density was measured using a plate reader (ClarioStar-BMG Labtech, Ortenberg, Germany) at $450 \mathrm{~nm}$ wavelength.

\subsection{RNA Extraction and RT-PCR}

Due to the large number of animals sampled, only a subset of 144 sera was selected across all sampled regions to be screened by PCR (Table 1) for four agriculturally relevant viruses (EHDV, BEFV, Pestivirus and Simbu serogroup). These included all the samples with ELISA-Ag positive and doubtful 
results. RNA was extracted from $140 \mu \mathrm{L}$ of serum or cell culture supernatant (positive controls) using a QIAamp ${ }^{\circledR}$ Viral RNA Mini Kit (Qiagen, Valencia, CA, USA), according to the manufacturer's instructions. Viral RNA was reverse transcribed using a Tetro cDNA Synthesis Kit (Bioline, London, UK) using random hexamers according to the manufacturer's directions. RNA extracted from in vitro cultures for Akabane Virus, BEFV, EHDV and one bovine serum sample confirmed to be positive for BVDV, were used as positive controls. All culture material and BVDV positive sera were kindly donated by the Department of Jobs, Precincts and Regions, Victoria. PCR amplification was performed in a $25 \mu \mathrm{L}$ reaction mixture containing $1 \times$ Green GoTaq Flexi buffer, $2 \mathrm{mM}$ of $\mathrm{MgCl}_{2}, 10 \mathrm{mM}$ of dNTPs, $0.2 \mu \mathrm{M}$ of both forward and reverse primers (Table 2), 0.625 units of GoTaq G2 DNA polymerase (Promega, Madison, WI, USA) and $1 \mu \mathrm{L}$ of total genomic DNA template. PCR primers were obtained from the literature for the four viruses included in this study (Table 2 and references therein). Amplification was carried out in a T100 thermal cycler (BioRad, Hercules, CA, USA), and amplification products visualized by gel electrophoresis, using $2 \%$ agarose gel, RedSafe ${ }^{\mathrm{TM}}$ (iNtRON Biotechnology, Gyeonggi-do, Korea), and a high-resolution imaging system-ChemiDoc ${ }^{\mathrm{TM}}$ MP Imaging System (Bio-Rad, Hercules, CA, USA).

\subsection{Statistical Analysis}

Samples were categorized as "positive" or "negative" based on the results of the ELISA-Ab. Seroprevalence was calculated from the proportion of seropositive results of those tested and is presented with 95\% confidence interval (CI), calculated using the Wilson score interval (www.epitools. ausvet.com.au). Binary logistic regression models were used to evaluate the effect of the sex, age category and sampling site on the antibody status. Logistic regression was performed using $\mathrm{R}$ version 4.0.0 (R Development Core Team, Vienna, Austria). Due to the sparse nature of the data, we performed the logistic regression analysis only on fallow deer (in which most of the positive samples were detected). Lastly, we used the two-tailed Fisher's exact test to evaluate the hypothesis of non-random distribution of positive samples between fallow and rusa deer. $p<0.05$ was considered statistically significant. 
Table 2. List of oligonucleotides and PCR conditions used in this study.

\begin{tabular}{|c|c|c|c|c|c|c|}
\hline Virus & Target Region & Primer Name & Sequence $5^{\prime}-3^{\prime}$ & Amplicon Length (bp) & PCR Condition & Reference \\
\hline \multirow{2}{*}{ Pestivirus } & \multirow{2}{*}{$5^{\prime} \mathrm{UTR}$} & 324 & ATGCCCWTAGTAGGACTAGCA & \multirow{2}{*}{288} & $95^{\circ} \mathrm{C} \times 2 \min 40$ cycles $\left(95^{\circ} \mathrm{C} \times 45 \mathrm{~s}, 52^{\circ} \mathrm{C}\right.$ & \multirow{2}{*}{ [11] } \\
\hline & & 326 & WCAACTCCATGTGCCATGTAC & & $\left.\times 45 \mathrm{~s}, 72{ }^{\circ} \mathrm{C} \times 45 \mathrm{~s}\right) 72{ }^{\circ} \mathrm{C} \times 5 \mathrm{~min}$ & \\
\hline \multirow{2}{*}{ Simbu Serogroup } & \multirow{2}{*}{ Segment S } & Uni-S-59F & GATGWCCWCAACGGAAT & \multirow{2}{*}{215} & $95^{\circ} \mathrm{C} \times 2 \min 40$ cycles $\left(95^{\circ} \mathrm{C} \times 45 \mathrm{~s}, 55^{\circ} \mathrm{C}\right.$ & \multirow{2}{*}{ [12] } \\
\hline & & Uni-S-254R & TGGGGAAAATGGTTATTAAC & & $\left.\times 45 \mathrm{~s}, 72{ }^{\circ} \mathrm{C} \times 45 \mathrm{~s}\right) 72{ }^{\circ} \mathrm{C} \times 5 \mathrm{~min}$ & \\
\hline \multirow{2}{*}{ BEFV } & \multirow{2}{*}{ Glucoprotein G } & GF & ATGTTCAAGGTCCTCATAATTACC & \multirow{2}{*}{1871} & $95^{\circ} \mathrm{C} \times 2 \min 40$ cycles $\left(95^{\circ} \mathrm{C} \times 45 \mathrm{~s}, 52^{\circ} \mathrm{C} \times\right.$ & \multirow{2}{*}{ [13] } \\
\hline & & GR & TAATGATCAAAGAACCTATCATCA & & $\left.45 \mathrm{~s}, 72{ }^{\circ} \mathrm{C} \times 2 \mathrm{~min}\right) 72{ }^{\circ} \mathrm{C} \times 5 \mathrm{~min}$ & \\
\hline \multirow{2}{*}{ EHDV } & \multirow{2}{*}{ NS3 } & NS3F & CAGCGCYWTATWCGATATTG & \multirow{2}{*}{533} & $95^{\circ} \mathrm{C} \times 2 \min 40$ cycles $\left(95^{\circ} \mathrm{C} \times 45 \mathrm{~s}, 55^{\circ} \mathrm{C}\right.$ & \multirow{2}{*}{ [14] } \\
\hline & & NS3R & TCCGGAGATACCTCCATTAC & & $\left.\times 45 \mathrm{~s}, 72{ }^{\circ} \mathrm{C} \times 60 \mathrm{~s}\right) 72{ }^{\circ} \mathrm{C} \times 5 \mathrm{~min}$ & \\
\hline
\end{tabular}




\section{Results}

\subsection{Deer Sampling and Distribution}

During the sampling period, 432 wild deer were sampled encompassing four deer species (200 fallow deer, 110 chital deer (Axis axis), 80 rusa deer and 42 sambar deer (Rusa unicolor)) across eastern Australia (Table 1). Sampling was conducted from November 2017 to November 2019, with most samples (72\%) collected between June and October (Table 1, Figure 1B). Slightly more females $(n=229)$ than males $(n=196)$ were sampled, while no information was available for seven animals (Table 1 , Figure 1D). Individuals were classified in three age categories based on morphological characteristics, including body size, tooth wear and antler growth: fawn ( $<1$ year), yearling ( 1 to $<2$ years) and adult ( $\geq 2$ years). Most of the samples came from adult individuals $(n=305)$, followed by yearlings $(n=103)$ and fawns $(n=17)$. Information on age was not available for seven animals (Table 1, Figure 1C).

\subsection{ELISA Testing}

Sera and plasma samples from all 432 wild deer were screened by ELISA-Ab for Pestivirus and BoHV-1 (Table 1). All samples were negative for BoHV-1 antibodies. However, a total of 13 wild deer reacted positive for Pestivirus antibodies, resulting in an overall seroprevalence of $3.0 \%$. Of the Pestivirus seropositive deer, 46.2\% were sampled in June and 17.8\% in August. Of the positive samples, $85 \%$ were obtained from adults. Additionally, all Pestivirus positive samples were collected from fallow and rusa deer, with a $5.5 \%$ and a $2.5 \%$ Pestivirus-seropositivity for each species, respectively (Figure 2).

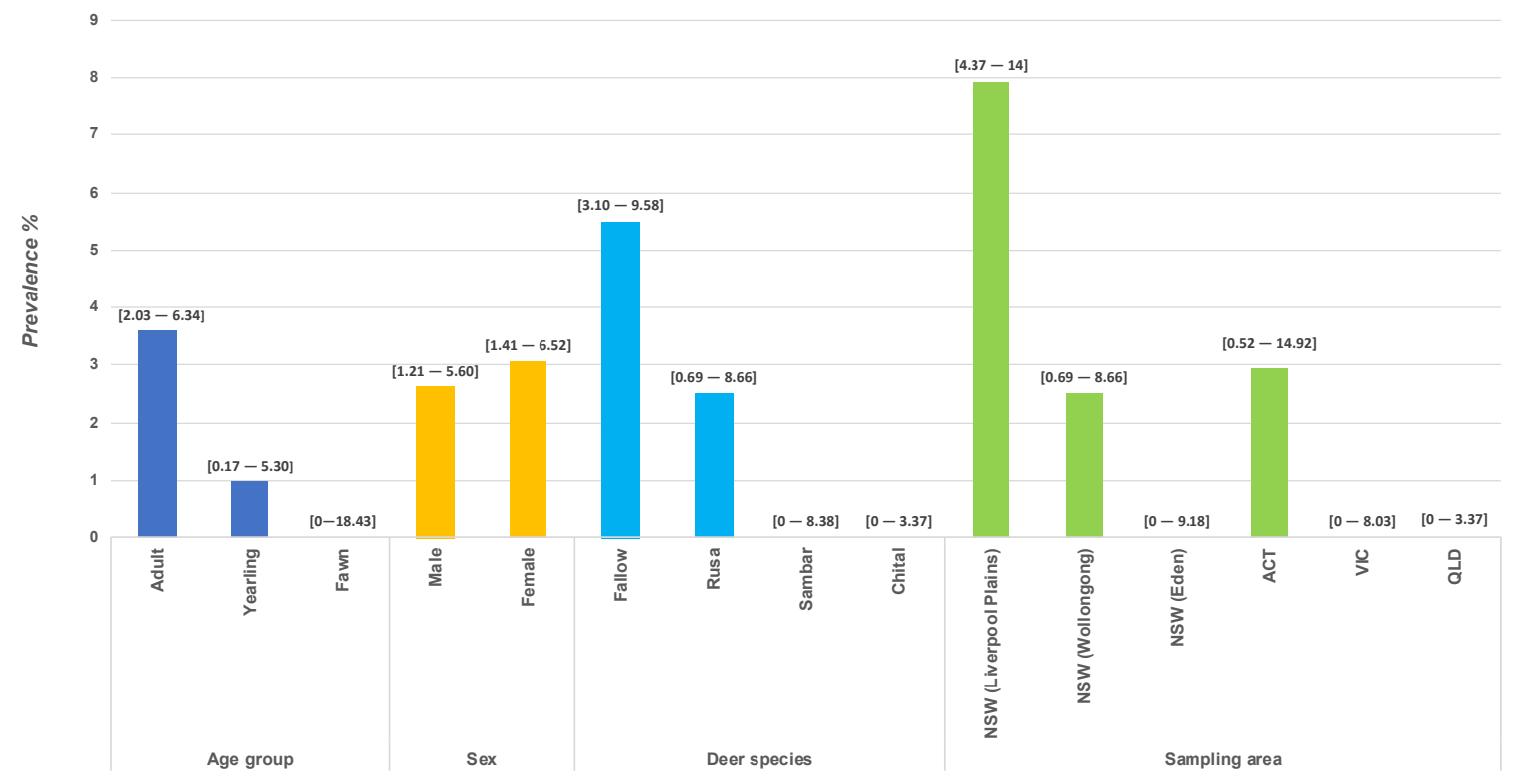

Figure 2. Prevalence of Pestivirus Antibodies: antibody prevalence was determined by ELISA and is represented as prevalence across age group, sex, species and sampling area. The $95 \%$ confidence interval is shown in brackets.

The animals positive for Pestivirus ELISA-Ab were sampled in Australian Capital Territory (ACT; 7.7\%) and New South Wales (NSW; 92.3\%). Two out of the three sampling areas from this last state showed seropositive deer with a local prevalence of 7.94\% in central NSW (Liverpool Plains), and $2.5 \%$ in coastal NSW (Wollongong) (Figure 2). Five of the 13 wild deer reacted as strong positives with test values (\%INH) ranging between $80-92 \%$; the remaining eight wild deer were weak positives with percentages ranging between $51-79 \%$ (Table 3 ). 
Table 3. Description of deer samples that tested positive for Pestivirus antibodies.

\begin{tabular}{|c|c|c|c|c|c|c|c|c|c|}
\hline \multirow{3}{*}{ Sample } & \multirow{3}{*}{ Species } & \multirow{3}{*}{ Sampling Month } & \multirow{3}{*}{ Sex } & \multirow{3}{*}{ Age } & \multirow{3}{*}{ Location } & \multicolumn{4}{|c|}{ Anti-Pestivirus ELISA } \\
\hline & & & & & & \multicolumn{2}{|c|}{ Serum } & \multicolumn{2}{|c|}{ Plasma } \\
\hline & & & & & & Result & \%INH $^{a}$ & Result & $\% \mathrm{INH}^{\mathrm{a}}$ \\
\hline 1 & Fallow & June & $\mathrm{F}$ & Ad & New South Wales & WP & 65 & $\mathrm{Neg}$ & - \\
\hline 2 & Fallow & June & $\mathrm{F}$ & Ad & New South Wales & SP & 91.9 & $\mathrm{SP}$ & 91.4 \\
\hline 3 & Fallow & June & F & Ad & New South Wales & WP & 73.7 & WP & 57.4 \\
\hline 4 & Fallow & June & $\mathrm{F}$ & Yrl & New South Wales & WP & 73.6 & WP & 59.0 \\
\hline 5 & Fallow & June & $\mathrm{F}$ & Ad & New South Wales & WP & 61.6 & WP & 67.0 \\
\hline 6 & Fallow & August & M & Ad & New South Wales & WP & 71.6 & WP & 67.1 \\
\hline 7 & Fallow & August & $\mathrm{M}$ & Ad & New South Wales & $\mathrm{SP}$ & 80.1 & WP & 79.4 \\
\hline 8 & Fallow & August & $\mathrm{M}$ & Ad & New South Wales & SP & 84.4 & $\mathrm{SP}$ & 83.3 \\
\hline 9 & Fallow & August & $\mathrm{M}$ & Ad & New South Wales & SP & 87.2 & $\mathrm{SP}$ & 80.1 \\
\hline 10 & Fallow & August & $\mathrm{M}$ & Ad & New South Wales & SP & 87.2 & WP & 78.9 \\
\hline 11 & Rusa & February & ND & ND & New South Wales & WP & 51.8 & NS & - \\
\hline 12 & Rusa & October & $\mathrm{F}$ & Ad & New South Wales & Neg & - & WP & 60.1 \\
\hline 13 & Fallow & June & M & Ad & Australian Capital Territory & NS & - & WP & 56.4 \\
\hline
\end{tabular}

a \%INH: percentage of inhibition obtained by ELISA; ND: no data, F: female, M: male, Ad: adult, Yrl: yearling; WP: weak positive, SP: strong positive, NS: no sample, Neg: negative. 
Additionally, 321 out the 432 wild deer were also tested for Pestivirus antigens (see Table 1). Of the 321 deer tested, $278(86.6 \%)$ showed a negative result, 24 (7.5\%) revealed a doubtful result and $19(5.9 \%)$ reacted positive. Additionally, only two of these positives overlapped with positive results shown for the ELISA-Ab screen.

Due to quasi-complete separation (i.e., most of the positives were in one category), we initially limited the predictors to the main effect of sex and age category (adult, yearling and fawn) or sex and location, and then tried to further simplify the model by considering sex only. In all models, the effect of the variables was not significant $(p>0.05)$. The proportion of seropositive Pestivirus results for fallow and rusa deer was similar $(p=0.36)$.

\subsection{RT-PCR Screening}

From the whole biobank of sera, 144 samples (see Table 1) were selected to be tested for Pestivirus, EDHV, BEFV and Simbu serogroup using previously validated RT-PCR primers sets [11-14]. These included all samples that had a doubtful or positive reaction for ELISA-Ag. Samples with hemolysis and insufficient volume were not included in the screening. No positive PCR amplification was obtained for any of the viruses screened, however, a positive result was obtained for all positive control samples in all runs.

\section{Discussion}

Australia's wild deer populations have increased in abundance and distribution during recent decades, and the close interaction between deer and livestock is a risk for pathogen transmission. However, little is known about the epidemiological role of wild deer in Australia. This study constitutes the largest number of deer, and deer species, sampled in Australia to date for viral pathogens, and complements a recent study performed on a similarly large number of animals across multiple geographic locations for the presence of parasitic infections [15]. Moreover, this study indicates exposure of deer to Pestivirus and is the first report of antibodies to ruminant Pestiviruses in rusa deer. This baseline information is of value for monitoring the status of endemic livestock pathogens in Australian deer, and for evaluating the risk of disease transmission between wild deer and livestock.

Although numerous pathogens have been detected in different cervids worldwide, including agriculturally relevant viruses [2], there is scarce knowledge about the viral infection status of Australian wild deer populations, with only four previous serosurveys being performed on red, fallow and rusa deer, but limited in their geographical coverage [7-10]. In contrast, the present study is based on the assessment of large sample sizes from four deer species collected throughout eastern Australia.

Our findings reveal the presence of antibodies in Australian wild deer species, against ruminant Pestiviruses (BVDV and BDV), which infect a variety of wild and domestic ungulate species and are associated with severe economic losses in livestock production worldwide [16]. In this study, positive serologic reactions were recorded in fallow and rusa deer at similar rates. Although the serosurveys have been proven to be a fundamental tool when it comes to disease surveillance, serological testing used in this study cannot distinguish between BVDV and BDV infections.

To our knowledge, this is the first report of Pestivirus antibodies in rusa deer. Additionally, in accordance with our findings, Pestivirus antibodies were identified previously in Australian fallow deer [7,8]. Seropositive fallow deer were first reported by Munday et al. (1972) [7] in Tasmania, with a prevalence of $14.5 \%$. Ten years later, another serosurvey described a prevalence of $1.2 \%(1 / 86)$ in fallow deer sourced from New South Wales [8], in an area also included in our study. Moreover, McKenzie et al. [9] reported a prevalence of $4 \%$ in red deer sourced from 20 localities in eastern Australia. In comparison with the previous report for fallow deer from New South Wales [8], a higher seroprevalence is reported in the present study. The use of a different detection assay could have influenced the prevalence obtained. Compared with previous Australian serosurveys that used a virus neutralization test targeting only BVDV1, we used a more robust immunoassay that could detect antibodies against BVDV1, BVDV2 and BDV. The higher seroprevalence in this study might also 
reflect a real change in prevalence in the last 40 years, possibly due to an increase in deer density leading to greater interaction with livestock. Although samples from red deer were not included in our analyses, seroprevalence detected in fallow and rusa deer is comparable to that described in red deer by McKenzie et al. [9]. These findings may indicate that red, fallow and rusa deer are similarly exposed to Pestivirus.

Fallow deer, chital deer and, to a lesser extent, rusa deer, are gregarious, and hence, their transmission of pathogens would be expected to be higher compared to sambar deer, which are usually solitary [17]. No seroprevalence for Pestivirus was observed for sambar deer in this study, however, sampling numbers were low in comparison to other species. The sampling location for sambar deer in this study was composed of forested areas within mountain landscapes mostly distant from livestock grazing areas; however, the chital deer samples were collected from within pastoral areas where they are known to interact with cattle.

There is conflicting evidence in the literature surrounding prevalence of Pestivirus in cervids and known contact with cattle. Studies [18-20] have reported that close contact with cattle can induce high seroprevalence in wild cervids; however, a study by Frolich et al. [21] contrasted these findings and hypothesized an independent cycle as responsible for intrapopulation persistence. Additionally, the identification of persistently infected mule deer (Odocoileus hemionus) [22] and white-tailed deer (Odocoileus virginianus) [23-25] suggests that BVDV can sustain itself in deer populations without contact with cattle. The susceptibility of sambar and chital deer to BVDV has not been demonstrated, and we cannot completely discount the lack of susceptibility as a possible cause of these negative results. However, it is possible that mortality of persistently infected animals or differences in social behavior between chital and sambar deer with the other deer species, which could also explain these negative results.

Most of the seropositive Pestivirus outcomes were recorded in adult deer, which is not unexpected, as they constituted $\sim 70 \%$ of the animals sampled in this study. Although antibody levels could be detected in the sampled deer, it is not possible to know when the animals were exposed to the virus. Seroconversion in cattle usually appears two weeks after infection, with the titer continuing to rise for 10 to 12 weeks; after this time, a plateau is reached [26,27]. Similarly, deer experimentally infected with BVDV exhibit a similar seroconversion course, developing antibodies at 8 to 15 days post infection [28,29]. However, antibodies against BVDV have been demonstrated to remain in serum for longer than three years [30].

Pestivirus antibody detection was performed in serum and plasma using a blocking ELISA kit with sensitivity and specificity comparable with other similar kits [31], also validated for non-bovine samples [32-34]. Concordance in results were found in eight overlapped specimens (serum and plasma), and two of the remaining overlapped specimens revealed positive outcomes only in one of the samples. Although this discrepancy is not enough to state which sample is better for Pestivirus antibody detection in deer, previous studies did not find variation between serum and plasma for viral antibody detection [35-37]. It is possible that other factors including the quality of the sample and antibody concentration could have affected the results in some samples.

Overall, the seroprevalence for Pestiviruses was 3\%, considerably lower than the $52.6 \%$ observed in Australian cattle [16]. Similar findings were detected in European countries during serosurveys of Pestiviruses in deer to evaluate the epidemiological importance of deer in BVDV eradication programs: Belgium, 1.3\% [38], Germany, 2\% [39], Switzerland, 2.7\% [3], and Italy, 4.5\% [40]. The authors concluded that despite regular interactions with farmed ruminants, infection in deer was occasional with virus transmission from cattle to deer, and therefore, the possibility of deer being a source of infection for cattle was remote.

In contrast to other reports, we did not detect any infected deer by PCR, although the RT-PCR assay we used detects a broad range of Pestiviruses from pigs, cattle and sheep [11]. Thus, based on detection of a low seroprevalence for ruminant Pestiviruses in the deer population studied, the fact that we did not identify any persistently infected (virus positive, antibodies negative) deer, and given 
the high number of seropositive cattle in Australia, we consider it more probable that deer are an accidental spillover host rather than a reservoir host for ruminant Pestiviruses, and that persistently infected cattle could transmit these viruses to wild deer.

Pestivirus antigen detection by ELISA resulted in $5.9 \%$ and $7.5 \%$ of samples testing positive and doubtful, respectively. However, RT-PCR negative results were obtained in all the samples. The ELISA kit utilized is reported to detect Pestivirus antigens in ruminant samples, however, there is no published information about validation with cervid samples. A similar antigen detection methodology was previously used for roe deer (Capreolus capreolus) [41], with positive results obtained. However, those findings were not confirmed by RT-PCR. A possible explanation for the false positive antigen results could be variations in the primer target region not detectable by RT-PCR used. A second explanation is that there were unspecific cross-reactions, but further work is needed to determine the exact cause of the potential false positive antigen ELISA results obtained in this study.

We acknowledge that a limitation of this study is the type of tissue utilized for detection of BVDV genetic material. Although there are studies that used serum to detect BVDV by PCR [42,43], BVDV has trophism for epithelia of both the alimentary and integumentary systems [44], however, due to the collection strategies available to us during the sampling procedures, specimens that would be more reliable in detecting low levels of viral nucleic acid over a longer period of infection time, such as reproductive tissues $[45,46]$ or spleen [47], were not available for testing.

BoHV-1 is the best characterized member of the subfamily Alphaherpesvirus, responsible for Infectious Bovine Rhinotracheitis (IBR), a cattle disease of major economic concern worldwide [48], and widespread in Australian cattle with a seroprevalence of $25-40 \%$ [49]. Susceptibility to BoHV-1 of wild cervids has previously been demonstrated [5,50], and additionally, several ruminant Alphaherpesviruses related to BoHV-1 have been isolated from cervids, including cervid herpesvirus 1 (CvHV-1) in red deer [51] and cervid herpesvirus 2 (CvHV-2) in reindeer (Rangifer tarandus) [52]. Our failure to detect antibodies against BoHV-1 is consistent with previous reports in Australia, which demonstrated an absence of BoHV-1 antibodies in fallow deer in Tasmania [7] and red deer in Queensland [9]. Furthermore, we can state that there is no evidence of cervid alphaherpesviruses in Australian wild deer, since serological cross reactivity by both virus neutralization and ELISA between ruminant alphaherpesviruses, including CvHV-1 and -2, is well documented [53-55].

The assessment of a subset of 144 serum samples by PCR also revealed no evidence of acute infection for the other viral livestock pathogens screened in this study. BEFV, EHDV and Akabane virus (a member of the Simbu serogroup) are endemic in Queensland and they have a seasonal spread in New South Wales [56-58]. Moreover, these viruses remain undetected in Victoria [57,58]. As they are vector-borne viruses, their occurrence is limited by the effect of cold weather, which restricts the distribution of their vectors. Previous studies performed in Australian deer reported serological evidence for BEFV, EHDV and Akabane virus in red deer from south-eastern Queensland [9]. Moreover, Moriarty et al. [10] found seropositive outcomes in a small sample of rusa deer in coastal central NSW for Akabane virus and EHDV. All the samples screened in the present study were negative for these viruses; however, the presence of vector species and previous evidence highlights the need for further serologic analysis to determine the role of deer as a spillover or reservoir host for these viruses, particularly in Queensland and New South Wales where BEFV, EHDV and Akabane virus are endemic. One limitation of this study was that all deer were sampled in the colder winter months, which would also lessen the activity of the vectors necessary for virus transmission.

\section{Conclusions}

Our findings provide an overview of the current Pestivirus infection status of wild deer in eastern Australia. The low prevalence of Pestivirus antibodies and negative findings for the viruses tested suggests that wild deer are an incidental spill-over host, and not a reservoir host. However, considering the substantial increase observed in fallow deer seroprevalence compared with a previous report [8], and the expected increase in distribution and abundance [1] (in the absence of substantial control), 
we cannot rule out the possibility that deer species sampled in this study could be a future source of infection for livestock.

Author Contributions: Conceptualization, C.P., T.G.C. and K.J.H.; methodology, J.L.H., C.P. and K.J.H.; formal analysis, J.L.H.; investigation, J.L.H., C.P. and K.J.H.; resources, C.P., D.M.F., A.P., J.O.H. and K.J.H.; data curation, J.L.H.; writing—original draft preparation, J.L.H. and K.J.H.; writing—review and editing, C.P., D.M.F., A.P., J.O.H., T.G.C. and K.J.H.; visualization, J.L.H. and K.J.H.; supervision, C.P., T.G.C. and K.J.H.; project administration, C.P., D.M.F., A.P., T.G.C. and K.J.H.; funding acquisition, C.P., D.M.F., A.P., T.G.C. and K.J.H. All authors have read and agreed to the published version of the manuscript.

Funding: This study was funded by the Centre for Invasive Species Solutions (PO1-L-002).

Acknowledgments: We would like to thank Richard Francis (ABZECO), Jake Haddad (VPAC), Kirk Stone (Strathbogie Wildlife), Andrew Bengsen, Troy Crittle and Quentin Hart (all New South Wales Department of Primary Industries), Bob McKinnon and Amy Sheridan (North West Local Land Services), Michael Brennan and Matt Amos (Biosecurity Queensland) and the staff from Parks Victoria for assisting with sample collection. In addition, we thank Kim O'Riley and Peter Mee for technical support. Finally, we thank Tao Zheng, PhD and Stacey Lynch, PhD from the Department of Jobs, Precincts and Regions, Victoria, for providing samples and cell culture supernatant used as positive controls.

Conflicts of Interest: The authors declare no conflict of interest.

\section{References}

1. Davis, N.E.; Bennett, A.; Forsyth, D.M.; Bowman, D.M.J.S.; Lefroy, E.C.; Wood, S.W.; Woolnough, A.P.; West, P.; Hampton, J.O.; Johnson, C.N. A systematic review of the impacts and management of introduced deer (family Cervidae) in Australia. Wildl. Res. 2016, 43, 515-532. [CrossRef]

2. Cripps, J.K.; Pacioni, C.; Scroggie, M.P.; Woolnough, A.P.; Ramsey, D.S.L. Introduced deer and their potential role in disease transmission to livestock in Australia. Mammal Rev. 2019, 49, 60-77. [CrossRef]

3. Casaubon, J.; Vogt, H.R.; Stalder, H.; Hug, C.; Ryser-Degiorgis, M.P. Bovine viral diarrhea virus in free-ranging wild ruminants in Switzerland: Low prevalence of infection despite regular interactions with domestic livestock. BMC Vet. Res. 2012, 8, 204. [CrossRef] [PubMed]

4. Duncan, C.; Backus, L.; Lynn, T.; Powers, B.; Salman, M. Passive, opportunistic wildlife disease surveillance in the Rocky Mountain Region, USA. Transbound. Emerg. Dis. 2008, 55, 308-314. [CrossRef]

5. Graham, D.A.; Gallagher, C.; Carden, R.F.; Lozano, J.M.; Moriarty, J.; O’Neill, R. A survey of free-ranging deer in Ireland for serological evidence of exposure to bovine viral diarrhoea virus, bovine herpes virus-1, bluetongue virus and Schmallenberg virus. Irel. Vet. J. 2017, 70, 13. [CrossRef]

6. Roug, A.; Swift, P.; Torres, S.; Jones, K.; Johnson, C.K. Serosurveillance for livestock pathogens in free-ranging mule deer (Odocoileus hemionus). PLoS ONE 2012, 7, e50600. [CrossRef]

7. Munday, B.L. A serological study of some infectious diseases of Tasmanian wildlife. J. Wildl. Dis. 1972, 8, 169-175. [CrossRef]

8. English, A.W. Serological survey of wild fallow deer (Dama dama) in New South Wales, Australia. Vet. Rec. 1982, 110, 153-154. [CrossRef]

9. McKenzie, R.A.; Green, P.E.; Thornton, A.M.; Chung, Y.S.; MacKenzie, A.R.; Cybinski, D.H.; St George, T.D. Diseases of deer in south eastern Queensland. Aust. Vet. J. 1985, 62, 424. [CrossRef]

10. Moriarty, A. Ecology and Enviromental Impact of Javan Rusa Deer (Cervus timorensis russa) in the Royal National Park. Ph.D. Thesis, University of Western Sydney, Sydney, NSW, Australia, 2004.

11. Vilcek, S.; Herring, A.J.; Herring, J.A.; Nettleton, P.F.; Lowings, J.P.; Paton, D.J. Pestiviruses isolated from pigs, cattle and sheep can be allocated into at least three genogroups using polymerase chain reaction and restriction endonuclease analysis. Arch. Virol. 1994, 136, 309-323. [CrossRef]

12. Golender, N.; Bumbarov, V.Y.; Erster, O.; Beer, M.; Khinich, Y.; Wernike, K. Development and validation of a universal S-segment-based real-time RT-PCR assay for the detection of Simbu serogroup viruses. J. Virol. Methods 2018, 261, 80-85. [CrossRef] [PubMed]

13. Kato, T.; Aizawa, M.; Takayoshi, K.; Kokuba, T.; Yanase, T.; Shirafuji, H.; Tsuda, T.; Yamakawa, M. Phylogenetic relationships of the $\mathrm{G}$ gene sequence of bovine ephemeral fever virus isolated in Japan, Taiwan and Australia. Vet. Microbiol. 2009, 137, 217-223. [CrossRef] 
14. Ohashi, S.; Yoshida, K.; Yanase, T.; Kato, T.; Tsuda, T. Simultaneous detection of bovine arboviruses using single-tube multiplex reverse transcription-polymerase chain reaction. J. Virol. Methods 2004, 120, 79-85. [CrossRef] [PubMed]

15. Huaman, J.L.; Pacioni, C.; Forsyth, D.M.; Pople, A.; Hampton, J.O.; Helbig, K.J.; Carvalho, T. Screening of Blood Parasites in Australian Wild Deer. Authorea 2020. [CrossRef]

16. Scharnbock, B.; Roch, F.F.; Richter, V.; Funke, C.; Firth, C.L.; Obritzhauser, W.; Baumgartner, W.; Kasbohrer, A.; Pinior, B. A meta-analysis of bovine viral diarrhoea virus (BVDV) prevalences in the global cattle population. Sci. Rep. 2018, 8, 14420. [CrossRef]

17. Van Dyck, S.; Strahan, R. The Mammals of Australia; Reed New Holland: Sydney, NSW, Australia, 2008.

18. Aguirre, A.A.; Hansen, D.E.; Starkey, E.E.; Mclean, R.G. Serologic Survey of Wild Cervids for Potential Disease Agents in Selected National-Parks in the United-States. Prev. Vet. Med. 1995, 21, 313-322. [CrossRef]

19. Rodriguez-Prieto, V.; Kukielka, D.; Rivera-Arroyo, B.; Martinez-Lopez, B.; de las Heras, A.I.; Sanchez-Vizcaino, J.M.; Vicente, J. Evidence of shared bovine viral diarrhea infections between red deer and extensively raised cattle in south-central Spain. BMC Vet. Res. 2016, 12. [CrossRef]

20. Fernandez-Aguilar, X.; Lopez-Olvera, J.R.; Marco, I.; Rosell, R.; Colom-Cadena, A.; Soto-Heras, S.; Lavin, S.; Cabezon, O. Pestivirus in alpine wild ruminants and sympatric livestock from the Cantabrian Mountains, Spain. Vet. Rec. 2016, 178, U557-U586. [CrossRef] [PubMed]

21. Frolich, K. Bovine Virus Diarrhea and Mucosal Disease in Free-Ranging and Captive Deer (Cervidae) in Germany. J. Wildl. Dis. 1995, 31, 247-250. [CrossRef]

22. Duncan, C.; Van Campen, H.; Soto, S.; LeVan, I.K.; Baeten, L.A.; Miller, M.W. Persistent Bovine viral diarrhea virus infection in wild cervids of Colorado. J. Vet. Diagn. Investig. 2008, 20, 650-653. [CrossRef]

23. Passler, T.; Walz, P.H.; Ditchkoff, S.S.; Walz, H.L.; Givens, M.D.; Brock, K.V. Evaluation of hunter-harvested white-tailed deer for evidence of bovine viral diarrhea virus infection in Alabama. J. Vet. Diagn. Investig. 2008, 20, 79-82. [CrossRef] [PubMed]

24. Duncan, C.; Ridpath, J.; Palmer, M.V.; Driskell, E.; Spraker, T. Histopathologic and immunohistochemical findings in two white-tailed deer fawns persistently infected with Bovine viral diarrhea virus. J. Vet. Diagn. Investig. 2008, 20, 289-296. [CrossRef] [PubMed]

25. Passler, T.; Walz, P.H.; Ditchkoff, S.S.; Givens, M.D.; Maxwell, H.S.; Brock, K.V. Experimental persistent infection with bovine viral diarrhea virus in white-tailed deer. Vet. Microbiol. 2007, 122, 350-356. [CrossRef] [PubMed]

26. Collins, M.E.; Heaney, J.; Thomas, C.J.; Brownlie, J. Infectivity of pestivirus following persistence of acute infection. Vet. Microbiol. 2009, 138, 289-296. [CrossRef] [PubMed]

27. Howard, C.J. Immunological responses to bovine virus diarrhoea virus infections. Rev. Sci. Tech. 1990, 9, 95-103. [CrossRef]

28. Van Campen, H.; Williams, E.S.; Edwards, J.; Cook, W.; Stout, G. Experimental infection of deer with bovine viral diarrhea virus. J. Wildl. Dis. 1997, 33, 567-573. [CrossRef]

29. Tessaro, S.V.; Carman, P.S.; Deregt, D. Viremia and virus shedding in elk infected with type 1 and virulent type 2 bovine viral diarrhea virus. J. Wildl. Dis. 1999, 35, 671-677. [CrossRef]

30. Fredriksen, B.; Sandvik, T.; Loken, T.; Odegaard, S.A. Level and duration of serum antibodies in cattle infected experimentally and naturally with bovine virus diarrhoea virus. Vet. Rec. 1999, 144, 111-114. [CrossRef]

31. Hanon, J.B.; De Baere, M.; De la Ferte, C.; Roelandt, S.; Van der Stede, Y.; Cay, B. Evaluation of 16 commercial antibody ELISAs for the detection of bovine viral diarrhea virus-specific antibodies in serum and milk using well-characterized sample panels. J. Vet. Diagn. Investig. 2017, 29, 833-843. [CrossRef]

32. Morrondo, M.P.; Perez-Creo, A.; Prieto, A.; Cabanelas, E.; Diaz-Cao, J.M.; Arias, M.S.; Fernandez, P.D.; Pajares, G.; Remesar, S.; Lopez-Sandez, C.M.; et al. Prevalence and distribution of infectious and parasitic agents in roe deer from Spain and their possible role as reservoirs. Ital. J. Anim. Sci. 2017, 16, 266-274. [CrossRef]

33. Loeffen, W.L.; van Beuningen, A.; Quak, S.; Elbers, A.R. Seroprevalence and risk factors for the presence of ruminant pestiviruses in the Dutch swine population. Vet. Microbiol. 2009, 136, 240-245. [CrossRef] [PubMed]

34. Evans, C.A.; Lanyon, S.R.; Reichel, M.P. Investigation of AGID and two commercial ELISAs for the detection of Bovine viral diarrhea virus-specific antibodies in sheep serum. J. Vet. Diagn. Investig. 2017, 29, 181-185. [CrossRef] [PubMed] 
35. Cherpes, T.L.; Meyn, L.A.; Hillier, S.L. Plasma versus serum for detection of herpes simplex virus type 2-specific immunoglobulin G antibodies with a glycoprotein G2-based enzyme immunoassay. J. Clin. Microbiol. 2003, 41, 2758-2759. [CrossRef]

36. Parra-Álvarez, S.; Coronel-Ruiz, C.; Castilla, M.G.; Velandia-Romero, M.L.; Castellanos, J.E. Alta correlación en la detección de anticuerpos y antígenos de virus del dengue en muestras de suero y plasma. Rev. Fac. Med. 2015, 63, 687-693. [CrossRef]

37. Lin, H.T.; Hsu, C.H.; Tsai, H.J.; Lin, C.H.; Lo, P.Y.; Wang, S.L.; Wang, L.C. Influenza A plasma and serum virus antibody detection comparison in dogs using blocking enzyme-linked immunosorbent assay. Vet. World 2015, 8, 580-583. [CrossRef]

38. Tavernier, P.; Sys, S.U.; De Clercq, K.; De Leeuw, I.; Caij, A.B.; De Baere, M.; De Regge, N.; Fretin, D.; Roupie, V.; Govaerts, M.; et al. Serologic screening for 13 infectious agents in roe deer (Capreolus capreolus) in Flanders. Infect. Ecol. Epidemiol. 2015, 5, 29862. [CrossRef]

39. Krametter, R.; Nielsen, S.S.; Loitsch, A.; Froetscher, W.; Benetka, V.; Moestl, K.; Baumgartner, W. Pestivirus exposure in free-living and captive deer in Austria. J. Wildl. Dis. 2004, 40, 791-795. [CrossRef]

40. Cuteri, V.; Diverio, S.; Carnieletto, P.; Turilli, C.; Valente, C. Serological survey for antibodies against selected infectious agents among fallow deer (Dama dama) in central Italy. Zentralbl Veterinarmed B 1999, 46, 545-549. [CrossRef]

41. Boadella, M.; Carta, T.; Oleaga, A.; Pajares, G.; Munoz, M.; Gortazar, C. Serosurvey for selected pathogens in Iberian roe deer. BMC Vet. Res. 2010, 6, 51. [CrossRef]

42. Decaro, N.; Lucente, M.S.; Lanave, G.; Gargano, P.; Larocca, V.; Losurdo, M.; Ciambrone, L.; Marino, P.A.; Parisi, A.; Casalinuovo, F.; et al. Evidence for Circulation of Bovine Viral Diarrhoea Virus Type 2c in Ruminants in Southern Italy. Transbound. Emerg. Dis. 2017, 64, 1935-1944. [CrossRef]

43. Fernandez-Sirera, L.; Cabezon, O.; Dematteis, A.; Rossi, L.; Meneguz, P.G.; Gennero, M.S.; Allepuz, A.; Rosell, R.; Lavin, S.; Marco, I. Survey of Pestivirus infection in wild and domestic ungulates from south-western Italian Alps. Eur. J. Wildlife Res. 2012, 58, 425-431. [CrossRef]

44. Bianchi, M.V.; Silveira, S.; Mosena, A.C.S.; de Souza, S.O.; Konradt, G.; Canal, C.W.; Driemeier, D.; Pavarini, S.P. Pathological and virological features of skin lesions caused by BVDV in cattle. Braz. J. Microbiol. 2019, 50, 271-277. [CrossRef] [PubMed]

45. Grooms, D.L.; Brock, K.V.; Ward, L.A. Detection of bovine viral diarrhea virus in the ovaries of cattle acutely infected with bovine viral diarrhea virus. J. Vet. Diagn. Investig. 1998, 10, 125-129. [CrossRef] [PubMed]

46. Givens, M.D.; Heath, A.M.; Brock, K.V.; Brodersen, B.W.; Carson, R.L.; Stringfellow, D.A. Detection of bovine viral diarrhea virus in semen obtained after inoculation of seronegative postpubertal bulls. Am. J. Vet. Res. 2003, 64, 428-434. [CrossRef]

47. Ohmann, H.B. Pathogenesis of bovine viral diarrhoea-mucosal disease: Distribution and significance of BVDV antigen in diseased calves. Res. Vet. Sci. 1983, 34, 5-10. [CrossRef]

48. Thiry, J.; Keuser, V.; Muylkens, B.; Meurens, F.; Gogev, S.; Vanderplasschen, A.; Thiry, E. Ruminant alphaherpesviruses related to bovine herpesvirus 1. Vet. Res. 2006, 37, 169-190. [CrossRef]

49. Gu, X.; Kirkland, P.D. Infectious Bovine Rhinotracheitis. In Australian and New Zealand Standard Diagnostic Procedures; The Department of Agriculture and Water: Canberra, ACT, Australia, 2008; pp. 1-18.

50. Lillehaug, A.; Vikoren, T.; Larsen, I.L.; Akerstedt, J.; Tharaldsen, J.; Handeland, K. Antibodies to ruminant alpha-herpesviruses and pestiviruses in Norwegian cervids. J. Wildl. Dis. 2003, 39, 779-786. [CrossRef]

51. Inglis, D.M.; Bowie, J.M.; Allan, M.J.; Nettleton, P.F. Ocular disease in red deer calves associated with a herpesvirus infection. Vet. Rec. 1983, 113, 182-183. [CrossRef]

52. Ek-Kommonen, C.; Pelkonen, S.; Nettleton, P.F. Isolation of a herpesvirus serologically related to bovine herpesvirus 1 from a reindeer (Rangifer tarandus). Acta Vet. Scand. 1986, 27, 299-301.

53. Lyaku, J.R.S.; Nettleton, P.F.; Marsden, H. A Comparison of Serological Relationships among 5 Ruminant Alphaherpesviruses by Elisa. Arch. Virol. 1992, 124, 333-341. [CrossRef]

54. Martin, W.B.; Castrucci, G.; Frigeri, F.; Ferrari, M. A Serological Comparison of Some Animal Herpesviruses. Comp. Immunol. Microb. 1990, 13, 75-84. [CrossRef]

55. Nixon, P.; Edwards, S.; White, H. Serological Comparisons of Antigenically Related Herpesviruses in Cattle, Red Deer and Goats. Vet. Res. Commun. 1988, 12, 355-362. [CrossRef] [PubMed]

56. Walker, P.J.; Klement, E. Epidemiology and control of bovine ephemeral fever. Vet. Res. 2015, 46, 124. [CrossRef] [PubMed] 
57. Weir, R.P.; Agnihotri, K. Epizootic Haemorrhagic Disease. In Australian and New Zealand Standard Diagnostic Procedures; The Department of Agriculture and Water: Canberra, ACT, Australia, 2014; pp. 1-14.

58. Australia Animal Health. National Arbovirus Monitoring Program 2015-2016 Report. Available online: https://www.animalhealthaustralia.com.au/wp-content/uploads/2015/09/NAMP-Annual-Report_ FA_print.pdf (accessed on 1 April 2020).

(c) (

(C) 2020 by the authors. Licensee MDPI, Basel, Switzerland. This article is an open access article distributed under the terms and conditions of the Creative Commons Attribution (CC BY) license (http://creativecommons.org/licenses/by/4.0/). 